\title{
Debt Maturity Structure, Firm Value and Underinvestment Incentive - The Case of Pakistan
}

\author{
Syed Sikander Ali Shah*, Ali Murad Syed"* and Sana Sheikh ${ }^{* * *}$
}

\begin{abstract}
This study examines the potential interaction of a firm's financing and investment decisions. It studies broadly how firms manage underinvestment and liquidity risks. To estimate the effects of these decisions, the study has incorporated four simultaneous equations using the partial dynamic adjustment model. Panel data of non-financial Pakistani firms have been used in this study. The findings of this study demonstrate that Pakistani high growth firms depend on high-leverage strategies and give greater importance to underinvestment risk rather than liquidity risk. Furthermore, growing Pakistani firms are not adopting low-leverage strategies ex ante to participate in future growth opportunities ex post. This study also examines whether or not Pakistani firms are paying special attention to the mixing of debt maturity that affects the firm's investment decisions and its value.
\end{abstract}

Keywords: Liquidity risk; underinvestment; firm value; leverage; debt maturity

\section{JEL Classifications: G11; G11; G23; G31}

\section{Introduction}

A central issue within corporate finance is the practice of setting the policy of a firm's financing and investment decisions in order to receive optimal benefits and to share those benefits with the firm's investors. It seeks to prevent the potential risk (liquidity risk, bankruptcy risk, and the agency cost and underinvestment problem). For a levered firm, financing decisions area complex job, as these decisions can lead to agency problems and debt overhang due to asymmetric sharing of information among the managers and shareholders. If a firm attempts to raise funds internally, the availability of these funds is at a lower cost as

\footnotetext{
${ }^{*}$ PhD Scholar, University of Management and Technology, Pakistan.

** Assistant Professor, College of Business Administration, Imam Abdul Rahman Bin Faisal University, Saudi Arabia.

${ }^{* * *}$ PhD Scholar, National College of Business Administration and Economics, Pakistan.
} 
compared to external sources. Firms depend on low-leverage guides to encounter the agency problem (underinvestment and liquidity risk). Credit risk, liquidity risk and firm rating play a vital role in the selection of debt maturity and the level of leverage. Underinvestment problems arise when the firm has growth opportunities in the shape of positive NPV projects, but it is not able to invest in growth opportunities due to the unavailability of external funds. A firm can absorb every potential growth opportunity, if it adopts a policy of high leverage and relies more on short-term debt maturity. If we view it from another prospective it is difficult for a firm to rotate debt more frequently and renegotiate with lenders. Therefore, the firms that tend to rely more on short-term debt face a greater liquidity risk, pay heavy costs on debt and are more likely to file for bankruptcy.

In their seminal work Modigliani and Miller (1963) argued that there is no interaction between a firm's financing and investment decisions in a perfect market. Investment is necessary for a firm to grow its asset and adopt new technologies. A firm's financing decision plays a vital role in the process of valuing growth opportunities for the firm, and it must consider different dimensions e.g., selection of mixed financing, getting the maximum advantage of a tax shield, and setting the debt maturity structure. These decisions affect the investment policy and are not irreversible (Mauer \& Triantis, 1994). Firm financing and investment decisions set at the optimal level can maximize the value of a corporation. The financial policy variables are leverage, debt maturity and firm value. The investment policy variables are growth opportunities and investment.

The firm's capital structure and credit policy are designed to respond to growth opportunities and they each depend on the firm's individual characteristics (Goyal, Lehn, \& Racic, 2002, Billett, KING, \& Mauer, 2007, and Taleb \& AL-Shubiri). Macroeconomic conditions of the country also influence the firm's capital and debt maturity structure (Korajczyk \& Levy, 2003). There is an optimal debt level for a firm to finance its assets and any increase of debt from that level will likewise increase the debt-to-equity (D/E) ratio. This may affect the firm's value and can lead to bankruptcy as the benefit of debt in the form of tax shields will be below the level of cost of the new debt. As a result, leverage and firm value have shown a negative relationship. D/E ratio (a measure of leverage) limitations may be imposed by the industry benchmark, the lender's evaluation agency or any monitoring institution that ensures the liquidity and solvency of a specific industry. Debt maturity structure is a pattern of firm leverage, and it can be defined as multiple debts 
outstanding in a single period. The firm's debt maturity and ratio of $\mathrm{D} / \mathrm{E}$ directly influence the firm's value, and its economic relations play a role in developing correlation between debt and investment policy to curb the underinvestment problem and liquidity risk.

The relationship between financing and investment decisions is important for the survival and growth of any firm. Investment growth opportunities, investment, leverage and firm value are the main determinants of the grand debt strategy of any firm. How these variables interact can allow a firm to overcome the liquidity risk and underinvestment problem. It determines the debt policy, choices and pattern of low- and high-growth firms and high- and low-leverage firms. The investment decisions and funds forecasting to anticipate future growth opportunities are based on the interaction of leverage and debt maturity.

Moreover, firms need to examine whether the debt maturity structure or leverage is appropriate for its credit policy. The firm's efforts to establish a friendly relationship between principal and agent are affected by asymmetric information and market imperfections. Underinvestment incentive is one of the instruments which enhances or controls the agency problem.

This study is organized with the goal of examining interaction between financing and investment decisions. The interaction among firm financing decisions, debt maturity structure, investment growth opportunities, investment and firm value in the presence of the underinvestment problem are investigated. We used panel data from 12 major sectors of 424 non-financial listed, Pakistani firms in the KSE 100 index over the period of 1999 to 2008.

This study evaluates the debt pattern and policy of Pakistani firms which enables the firms' management to create the debt policy, in order to address the underinvestment and liquidity risk. Firms of developing countries always face the issues of leverage and growth opportunities; this is one reason Pakistani firms have been selected for this study. It is the authors' understanding that no study has been conducted in the Pakistani market which focuses on determinants of financing and investment decisions: the primary focus of this study. Another significant focus of this study is to investigate interactions among and between leverage, debt maturity structure, growth opportunity to investment, firm investment and firm value. Furthermore, it gives direction in four dimensions. The first dimension is a comprehensive policy design of 
corporate finance and investment by non-financial listed, Pakistani firms which supports investment opportunities at an optimal level or sets the level of leverage and debt maturity. As a result, the agency problem is offset (under investment problem). The second dimension involves seeking the moderate strategy for avoiding the liquidity shortfall that arises, particularly when the firm adopts the short-term debt maturity policy. Thirdly, the leverage and debt maturity are important pillars of the debt policy which will help the Pakistani investor to mitigate the underinvestment problem. Finally it emphasizes the role and importance of the firm value in designing the corporate finance and investment policy to capture the growth opportunity for investment. In this paper we will broadly describe how the Pakistani non-financial sector manages the underinvestment problem and liquidity risk.

The paper is structured as follows: A review of the existing literature on this particular research area is presented in Section 2, hypothesis testing, data collection and research methodology is described in Section 3, explanation of results and the significance of the findings are discussed in Section 4, and Sections 5 and 6 conclude the results with policy recommendations.

\section{Literature Review}

Choices of debt or equity, selection of maturity structure and payout policy are major decisions of any firm's financial policy. The firm's financing and investment decisions are independent of each other under the assumptions of a perfect market (Modigliani \& Miller, 1963). In reality many market frictions exist which establish a correlation between the firm's financial and investment decisions. Aggressive managers of high-growth firms have always made decisions in favor of shareholders (Myers, 1977). Furthermore, managers may forgo the positive (NPV) projects due to debt overhang problem; hence, debt plays a disciplinary role in the decision between under- or over-investment. Al Taleb and AlShubiri (2011) studied the debt maturity and capital structure decisions of industrial companies of Jordan and found that Jordanian companies use less debt in comparison to other companies within and outside of the region. Lewellen and Emery (1986) examined the debt policy and found that when a firm sets the maturity of debt, it considers the debt to total market value., The same study also found that the reason for the imbalance in debt maturity schedule is the anticipated future cash flows. 
The relationship between leverage, debt maturity and firm value is also discussed in previous research. Dang (2011) investigated the interaction between corporate financing and investment decisions to answer the question of how firms formulate joint choice between leverage and debt maturity to mitigate the underinvestment problem. The study concluded that the firms with high growth opportunities reduce financial leverage and the growth opportunities do not affect the debt maturity. The underinvestment incentives may be mitigated if the firm lowers its leverage or reduces the structure of its debt maturity. Risky debt may cause the problem of underinvestment debt overhang and at least partially accrues payoff of positive NPV projects to the shareholders instead of fully accruing to both the managers and shareholders. Furthermore, many researchers documented the relationship between firm value and leverage (Conroy, 2009; Fama \& French, 1998; Masulis, 1983). The trade-off theory by Myers (1977) has been proven by Lin and Chang (2011) by connecting the asymmetric information. Alcock, Finn, and Tan (2012) found the determinants of debt maturity of Australian firms to forecast a monotonic association between debt maturity and leverage. Their results support this monotonic relationship. They also investigated the interaction between maturity and leverage, and found that ignoring this interaction may lead to invalid conclusions to support the matching principle, hypothesis of agency costs and the hypothesis of transaction costs.

Current leverage and future growth opportunities decide the firm's behavior towards particular investment and is discussed in previous research. Lang, Ofek, and Stulz (1996) tested the relationship between the current leverage and future growth opportunities. They concluded that the variables display a negative relationship. Fernandez (2011) provided evidence of the disciplinary role of debt and determined that the relationship of the average firm's long-term leverage and investment is a strongly inverse one. This study also found that the leverage of firm with low growth has an inverse and statically insignificant relationship with the firm's investment decisions. Barclay and Smith (1995) have examined the determinants of corporate debt maturity and found that the firms having more growth options in the set of their investment opportunities were more concerned with short-term debt financing. This result is consistent with the argument by Myers (1977) that reduction of debt maturity mitigates the underinvestment problems. The authors also found that synchronized firms are subject to additional long-term debt. Tsurutani and Smith (1986) found that regulation reduces the firm's prudence more than the corporate 
investment policy, consequently calculating the underinvestment problem. Majumdar (2012) argued that collateralized assets and leverage are directly influenced by debt maturity. The same study found no evidence of a relationship between debt maturities structure and an effective growth tax shield. By contrast, Al Taleb and Al-Shubiri (2011) showed that growth and debt maturity are positively related. Firm debt maturity structure is defined as multiple debts issued by a firm with different maturities outstanding at the same time. Consequently, designing a debt maturity policy is a complex task that can reduce the deadweight cost of capital and achieve the "optimal liquidation" value (Houston \& Venkataraman, 1994). In the selection of debt maturity structure, a firm conducts a basic cost/benefit analysis. Korajczyk and Levy (2003) studied the benefits of the short- and long-term debt by using the partial dynamic model. They argued that short-term debt has more welfare for the organization, i.e., the calibration costs of long-term maturity is more than the associated costs of short-term debt. Another study provided evidence that short-term debt controls the agency cost arising from compensation risk (Brockman, Martin, \& Unlu, 2010). Firms rely on short-term debt rather than long-term in countries with higher levels of corruption, while firms in countries with less corruption hold more long-term debt than short-term. Finally, in countries that do not have explicit bankruptcy laws, firms have more leverage and choose long-term debt (Becher et al., 2012).

Firm financing and cash flows of investment create a conflict among the shareholders and managers, which in turn leads to the agency problem. Furthermore, this study empirically investigated that leverage, debt maturity and dividends are effective tools to reduce the dependence on cash flow for investment. Managers seek potential opportunities of investment to support the level of profit and return on capital, independently of the firm value and return on equity (Ting, 2012). The conflict between shareholders and bondholders can be reduced either by counting multifaceted provisions, i.e., bond covenants, security and call and conversion features, or by restricting the maturity of debt Bodie and Taggart 1978; Haugen and Senbet 1978; Myers 1977). Easterwood and Kadapakkam (1994) documented that risky debt is the cause of agency conflicts between shareholders and bondholders.

Previous literature shows relationships between growth, leverage, debt maturity, growth opportunities, firm value and underinvestment for different markets, but the interaction among these variables is missing in the previous studies. This paper investigates the relationships between 
leverage, investment, growth opportunities, debt maturity, and firm value in consideration of the underinvestment problem in non-financial firms of Pakistan. Based on the gap in existing literature, the following hypotheses are empirically tested to discuss the underinvestment incentive and liquidity risk in this study:

H1: There is a positive relationship between growth opportunities and leverage.

H2: There is a negative relationship between growth opportunities and debt maturity.

H3: There is a negative relationship between the leverage and debt maturity.

H4: There is a positive relationship between the growth opportunities on investment and firm value.

H5: There is a positive relationship between the investment and debt maturity.

H6: There is a positive relationship between the firm value and investment.

\section{Data and Methodology}

In this study, the model consists of five major determinants of debt policy. Taking each variable as a dependent variable one-by-one, the other four variables are regressed as independent variables on their respective dependent variable. The control variables are also included in the model. This delivers four simultaneous regression equations and the estimates of leverage, debt maturity, investment and firm value.

\subsection{Leverage Equation}

In the leverage equation, leverage has been taken as a dependent variable. It is defined as the book value of debt divided by the total debt plus market value of equity (Dang, 2011). The leverage equation has been formed using the model used by Ozkan (2001) and Dang (2011). Furthermore, there is an interaction between growth opportunity and maturity $\left(\mathrm{GTH}^{*} \mathrm{MAT}\right)$ and $\mathrm{X}^{\mathrm{LEV}}$ a vector of $\mathrm{i} \times \mathrm{k}$ which consists of four control variables, i.e., size, profitability, tangibility and non-debt tax shield. The interaction term is previously used by Johnson (2003) and Dang (2011) in their models. 


$$
\begin{aligned}
& \mathrm{LEV}_{\mathrm{i}, \mathrm{t}}= \alpha_{0}+\lambda_{\mathrm{LEV}} \mathrm{LEV}_{\mathrm{i}, \mathrm{t}-1}+\alpha_{1} \mathrm{MAT}_{\mathrm{i}, \mathrm{t}}+\alpha_{2} \mathrm{GTH}_{\mathrm{i}, \mathrm{t}}+\alpha_{3} \mathrm{FV}_{\mathrm{i}, \mathrm{t}}+\alpha_{4}(\mathrm{GTH} x \\
&\mathrm{MAT})_{\mathrm{i}, \mathrm{t}}+\mathrm{X}^{\mathrm{LEV}}{ }_{\mathrm{I}, \mathrm{t}} \alpha^{\mathrm{LEV}}+\mathrm{u}_{\mathrm{i}, \mathrm{t}}
\end{aligned}
$$

Debt maturity is defined as the long-term liability divided by the total outstanding debt. Growth opportunities are measured as the market value of equity plus book value of debt divided by total assets. Firm value is calculated as market value of cap plus minority interest, preferred stock and total debt minus the cash and cash equaling and lagged value capital expenditure plus depreciation divided by the total asset as a tool of investment measurement. Tangibility can be expressed as the ratio of fixed asset divided by total asset. Profitability is ratio of EBIT and total asset; size measured the lagged value of total asset and non-debt tax shield, the ratio of depreciation and total value of asset.

\subsection{Debt Maturity Equation}

The explanatory instrument of the Debt Maturity Equation are leverage, growth opportunities, firm value and a vector $(X)$ consisting of six determinants of debt maturity: firm size, firm quality, tax ratio, asset maturity structure, term structure of interest, and volatility (Antoniou et al., 2006).

$$
\begin{aligned}
\mathrm{MAT}_{\mathrm{i}, \mathrm{t}}= & \gamma_{0}+\lambda_{\mathrm{MAT}} \mathrm{MAT}_{\mathrm{i}, \mathrm{t}-1}+\gamma_{1} \mathrm{LEV}_{\mathrm{i}, \mathrm{t}}+\gamma_{2} \mathrm{GTH}_{\mathrm{i}, \mathrm{t}}+\gamma_{3} \mathrm{FV}_{\mathrm{i}, \mathrm{t}}+\gamma_{4}(\mathrm{GTH} \\
& \times \mathrm{LEV})_{\mathrm{i}, \mathrm{t}}+\mathrm{X}_{\mathrm{MAT}, \mathrm{t}} \gamma^{\mathrm{MAT}}+\mathrm{u}_{\mathrm{i}, \mathrm{t}}
\end{aligned}
$$

Asset maturity structure is defined as the net property plant equipment divided by depreciation. Interest rate differential is an interest rate of a ten-year government bond and three-year commercial papers or treasury bills. Tax paid divided by the pre-tax income is the measure of tax ratio. Volatility of cash flow can be explained as the EBITDA plus depreciation divided by the total asset.

\subsection{Investment Equation}

In this model, investment is a dependent variable and the variables of debt maturity, firm value, growth opportunity and leverage are regressed. Investment can be defined as the value which is obtained by dividing the capital expenditure plus depreciation by the total asset. Moreover, the investment equation has two interaction terms: growth opportunity $\times$ leverage and growth opportunity $\times$ debt maturity.

$$
\begin{aligned}
\mathrm{INV}_{\mathrm{i}, \mathrm{t}}= & \delta_{0}+\lambda_{\mathrm{INV} I N V_{\mathrm{I}, \mathrm{t}-1}+} \delta_{1} \mathrm{LEV}_{\mathrm{i}, \mathrm{t}}+\delta_{2} \mathrm{MAT}_{\mathrm{i}, \mathrm{t}}+\delta_{3} \mathrm{GTH}_{\mathrm{i}, \mathrm{t}}+\delta_{4} \mathrm{FV}_{\mathrm{i}, \mathrm{t}}+ \\
& \delta_{5} \mathrm{GTH} \times \mathrm{LEV}_{\mathrm{i}, \mathrm{t}}+\delta_{6}(\mathrm{GTH} \times \mathrm{MAT})_{\mathrm{i}, \mathrm{t}}+\delta_{7} \mathrm{CF}_{\mathrm{i}, \mathrm{t}}+\mu_{\mathrm{i}, \mathrm{t}}
\end{aligned}
$$


Where CF cash flow is an additional explanatory variable and $\mu_{\mathrm{i}, \mathrm{t}}$ is the error term with respect to a specific industry.

\subsection{Firm Value Equation}

In this model, firm value is dependent on the debt maturity, investment, investment to growth, leverage. Three interaction terms are explanatory variables and two interaction terms areGTH $\times \mathrm{LEV}$ and GTH $\times$ MAT.

$$
\begin{aligned}
& \mathrm{FV}_{\mathrm{i}, \mathrm{t}}=\beta_{0}+\lambda_{\mathrm{FV}} \mathrm{FV}_{\mathrm{i}, \mathrm{t}-1}+\aleph_{1} \mathrm{LEV}_{\mathrm{i}, \mathrm{t}}+\beta_{2} \mathrm{GTH}_{\mathrm{i}, \mathrm{t}}+\beta_{3} \mathrm{MAT}_{\mathrm{i}, \mathrm{t}}+\aleph_{4} \mathrm{INV}_{\mathrm{i}, \mathrm{t}}+\aleph_{5} \\
& (\mathrm{GTH} \times \mathrm{LEV})_{\mathrm{i}, \mathrm{t}}+\AA_{6}(\mathrm{GTH} \times \mathrm{MAT})_{\mathrm{i}, \mathrm{t}}+\mathrm{X}_{\mathrm{I}, \mathrm{t}}^{\mathrm{FV}} \mathrm{B}_{7} \mathrm{FV}+\mu_{\mathrm{i}, \mathrm{t}}
\end{aligned}
$$

\subsection{Data}

This study examined unbalanced panel data of non-financial, Pakistani firms listed in the KSE 100 Index. Data have been collected from yearly financial statements of the companies, database of State Bank of Pakistan (SBP) and the KSE 100 Index. Financial sector firms are not included in our sample. The companies that have four-year data are included in the dataset. Finally, the variables at the $1^{\text {st }}$ and 99th percentile are removed as outliers. Our panel data consist of 427 firms from 12 major sectors of Pakistan, taking 4270 observations from 1999 to 2008.

\subsection{Methodology}

In four simultaneous equations our dynamic partial model was applied, and the lagged value of the endogenous variable was added in the explanatory variables. This model is more appropriate for dynamic rather than static panels (Antoniou, Guney, and Paudyal 2006). The twostage estimation approach is the commonly-used measure to identify the most accurate instrument for the endogenous variables. To improve the efficiency of the estimation, we adopted IV and (GMM) generalized method of movement second stage estimation. To run IV, the second lagged value of endogenous variables was used as an instrument. In IV, the approach of the dynamic first difference of value is to eliminate the potential correlation with the lagged dependent variable, e.g., the second lagged $\mathrm{MAT}_{\mathrm{i}, \mathrm{t}-2}$ is the instrument of the first lagged value, $\mathrm{MAT}_{\mathrm{i}, \mathrm{t}-\mathrm{1}}$. This approach has been set for the other three equations: leverage, investment and firm value. 
To check the robustness of the results, we also ran the two-step GMM for improving the efficiency of IV estimation.

\section{Empirical Results}

Table 1 presents the summary of descriptive statistics of all variables used in this study.

\section{Table 1 - Summary Statistics}

\begin{tabular}{|c|c|c|c|c|c|}
\hline Variable & Obs & Mean & Std.Dev & Min & Max \\
\hline Debt Maturity & 2087.000 & 0.263 & 0.190 & 0.000 & 0.779 \\
\hline Leverage & 2047.000 & 0.829 & 1.157 & $(1.457)$ & 6.135 \\
\hline Investment & 3240.000 & 0.058 & 0.441 & $(1.194)$ & 2.654 \\
\hline Firm Value & 3856.000 & 2247.794 & 5015.424 & 0.710 & 48941.070 \\
\hline Growth Opportunity & 3823.000 & 0.950 & 0.883 & $(8.346)$ & 1.848 \\
\hline Leverage Growth & 2026.000 & 1.371 & 1.765 & $(0.277)$ & 11.791 \\
\hline Debt Maturity & 2026.000 & 0.267 & 0.211 & $(0.249)$ & 0.808 \\
\hline Tax Ratio & 3397.000 & 0.433 & 6.909 & $(1.222)$ & 380.525 \\
\hline Cash Flow & 3783.000 & 0.129 & 0.114 & $(0.239)$ & 0.633 \\
\hline Profitability & 3817.000 & 0.067 & 0.125 & $(0.336)$ & 0.596 \\
\hline Size & 3870.000 & 2.880 & 0.705 & 0.079 & 4.756 \\
\hline Assets Maturity & 3808.000 & 17.245 & 21.211 & 0.348 & 288.308 \\
\hline Earning Volatility & 3251.000 & 0.188 & 2.495 & $(14.344)$ & 17.093 \\
\hline Tangibility & 3868.000 & 0.516 & 0.235 & 0.001 & 0.976 \\
\hline Term Structure & 2989.000 & 0.025 & 0.011 & 0.014 & 0.043 \\
\hline None Debt Tax Shield & 3807.000 & 0.039 & 0.021 & 0.000 & 0.102 \\
\hline Firm Quality & 3221.000 & 169.753 & 1883.740 & $(4650.800)$ & 44367.510 \\
\hline
\end{tabular}

\subsection{Empirical Results of Leverage Equation}

Table 2 and 3 shows the empirical finding of the IV approach and the two-step GMM results. 


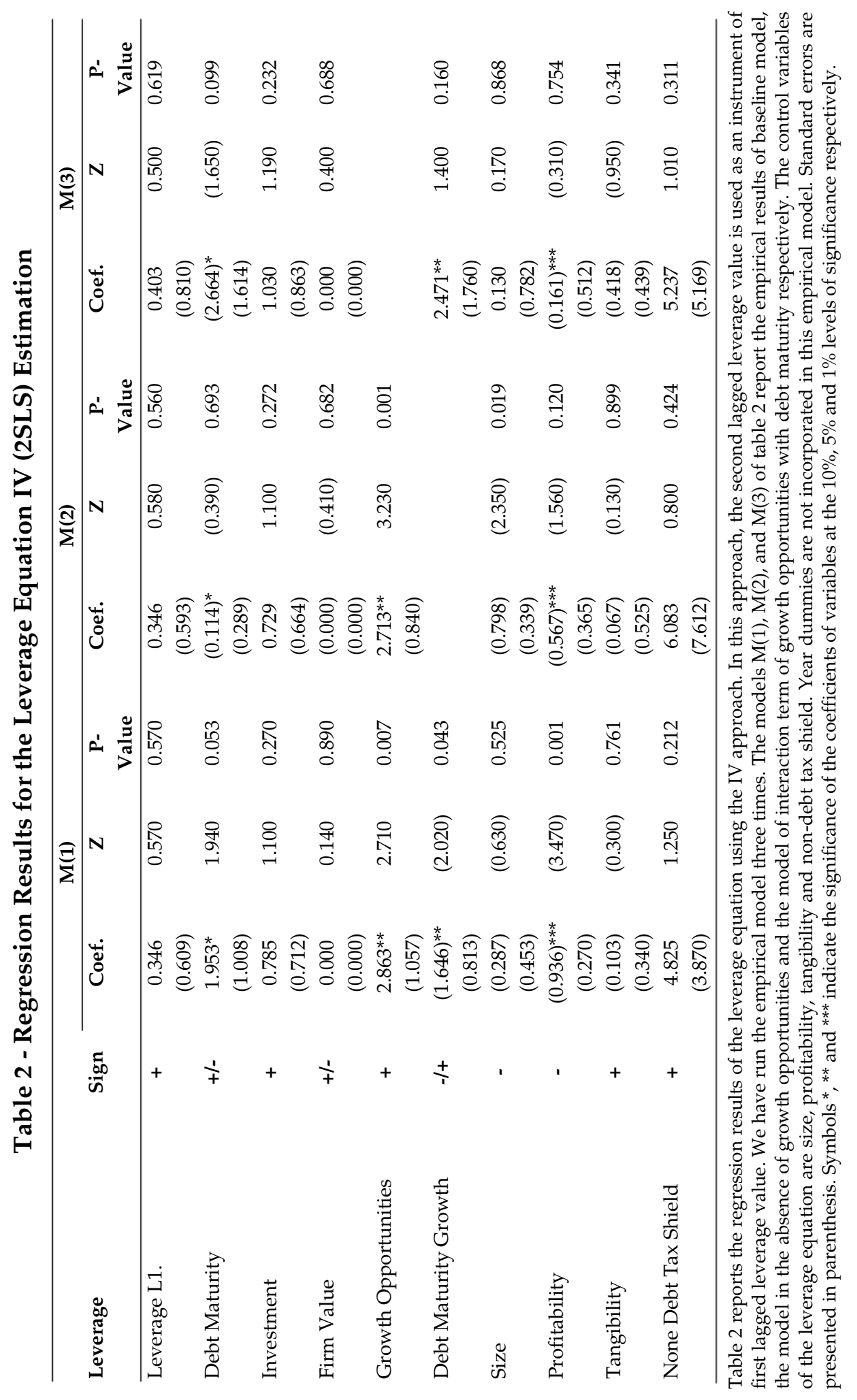




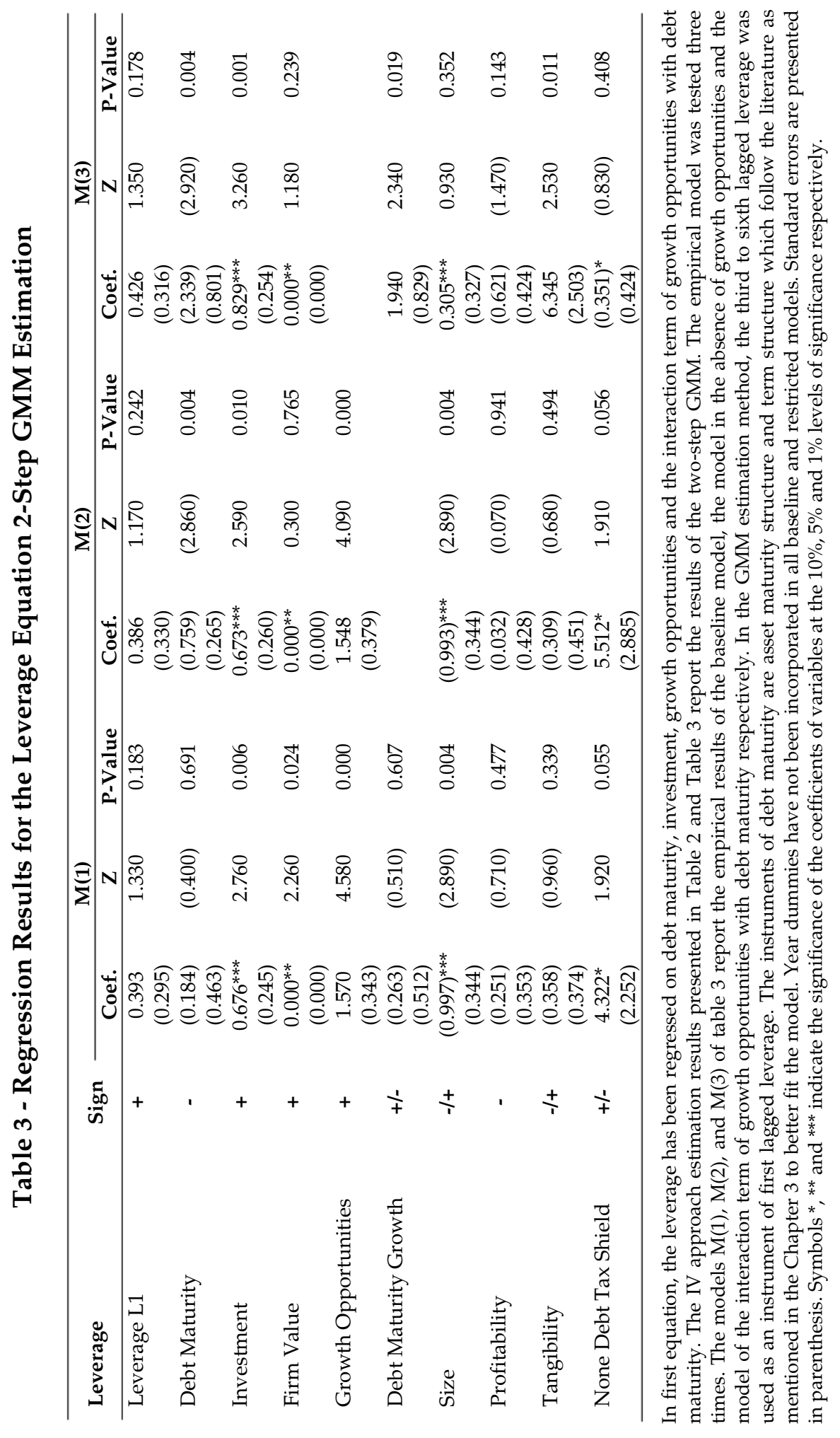


Table 2 reports the regression results of leverage equation using the IV approach. In this approach, the second lagged leverage value has been used as an instrument of the first lagged leverage value. We ran the empirical model three times for both tables. The models $\mathrm{M}(1), \mathrm{M}(2)$, and $\mathrm{M}(3)$ of table 2 report the empirical results of the baseline model, the model in the absence of growth opportunities and the model of interaction term of growth opportunities with debt maturity, respectively.

In the GMM estimation method, the third to sixth lagged leverage has been used as an instrument of first lagged leverage. Growth opportunities are positively significant in the IV approach and the GMM estimator. These findings are consistent with the existing literature (Myers; 1977) (Johnson, 2003; Ozkan, 2001), in that growth opportunities have a direct relationship with leverage and support the underinvestment hypothesis In the two-step GMM table, the variable investment of the firm and value of the firm has a significant relationship with the leverage.

\subsection{Empirical Equation of Debt Maturity Equation}

Table 4 reports the IV approach and Table 5 presents the two-step GMM estimator. 


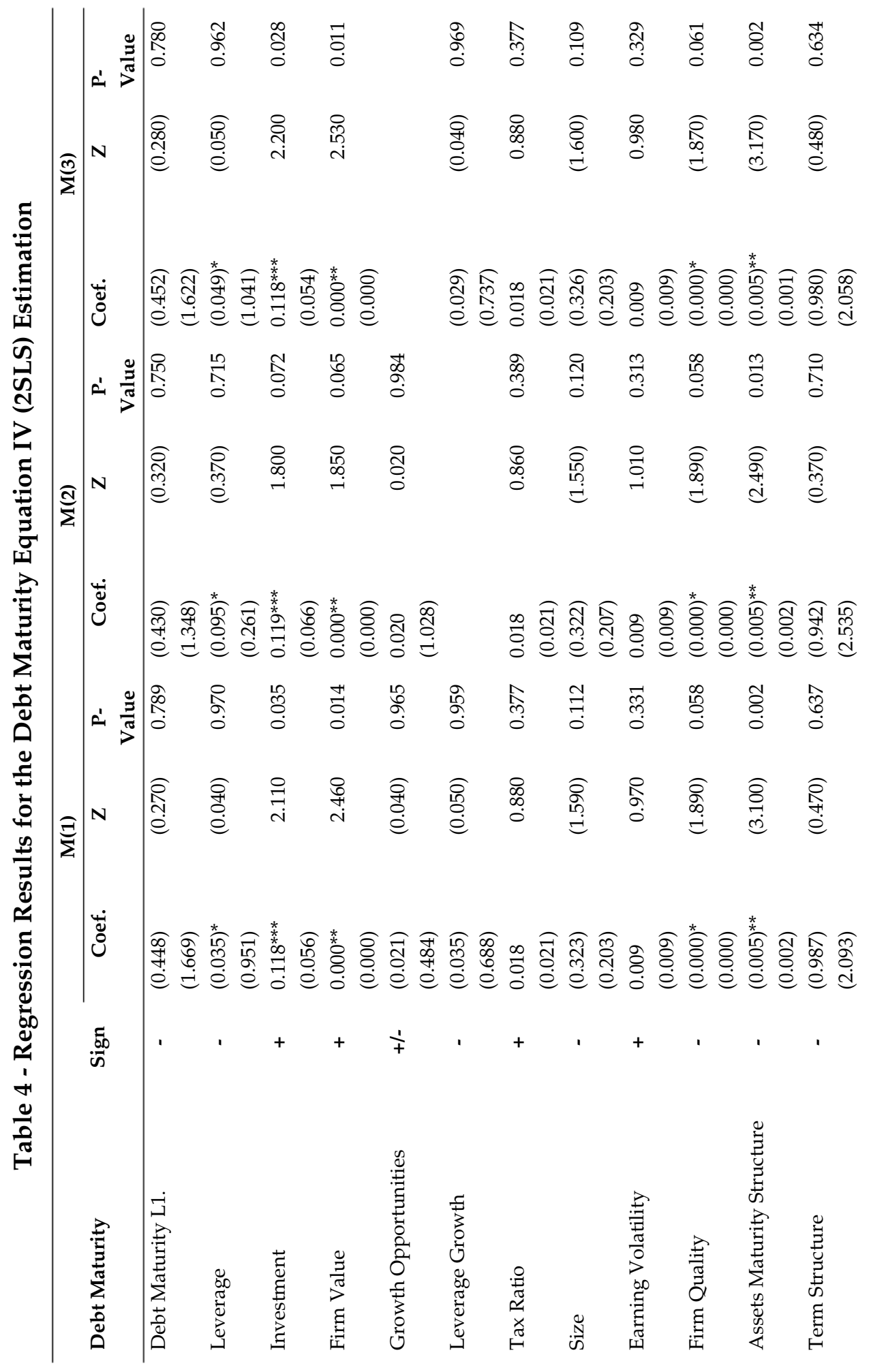




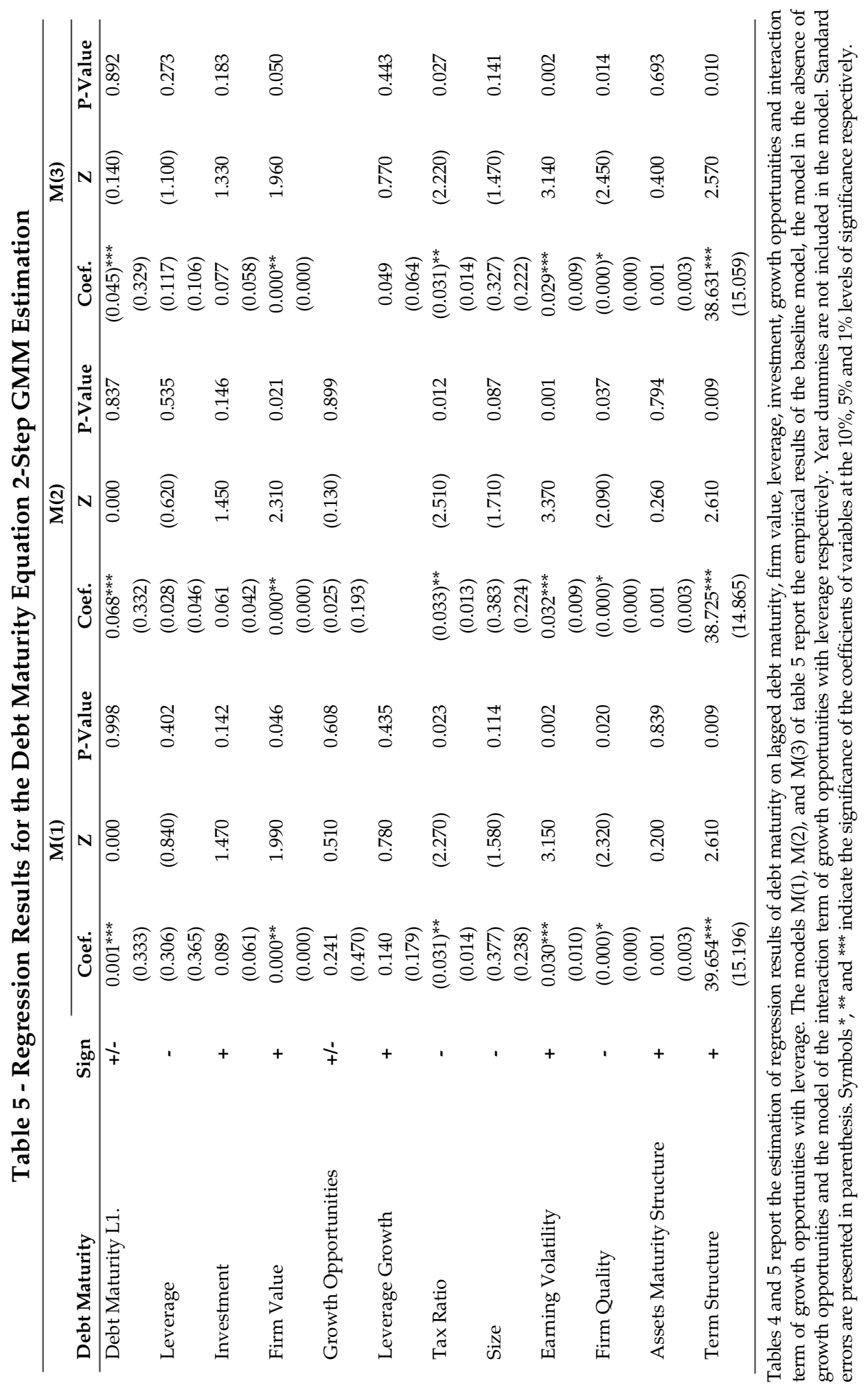


The control variable, firm quality and asset maturity structure are significant at $10 \%$ and $1 \%$ in the IV approach. Regarding the control variables, firm quality, earning volatility and term structure are significant in the two-step GMM estimator. Growth opportunities and its interaction term with leverage have no economic significant relationship with debt maturity in all six empirical models. These results are consistent with the findings of other recent research (Dang, 2011).

At $10 \%$ significance level, leverage has an economic relationship while using the IV approach and has no relationship in the GMM estimator. The relationship of leverage is significant in the first three models., The relationship is negative which is consistent with the results of Johnson (2003). Furthermore, the growth opportunities gets significance in other modified models because of the potential attenuation effect.

\subsection{Empirical Results of Investment Equation}

Table 6 reports the IV estimation results and Table 7 presents the two-stage GMM estimator. 

The Case of Pakistan

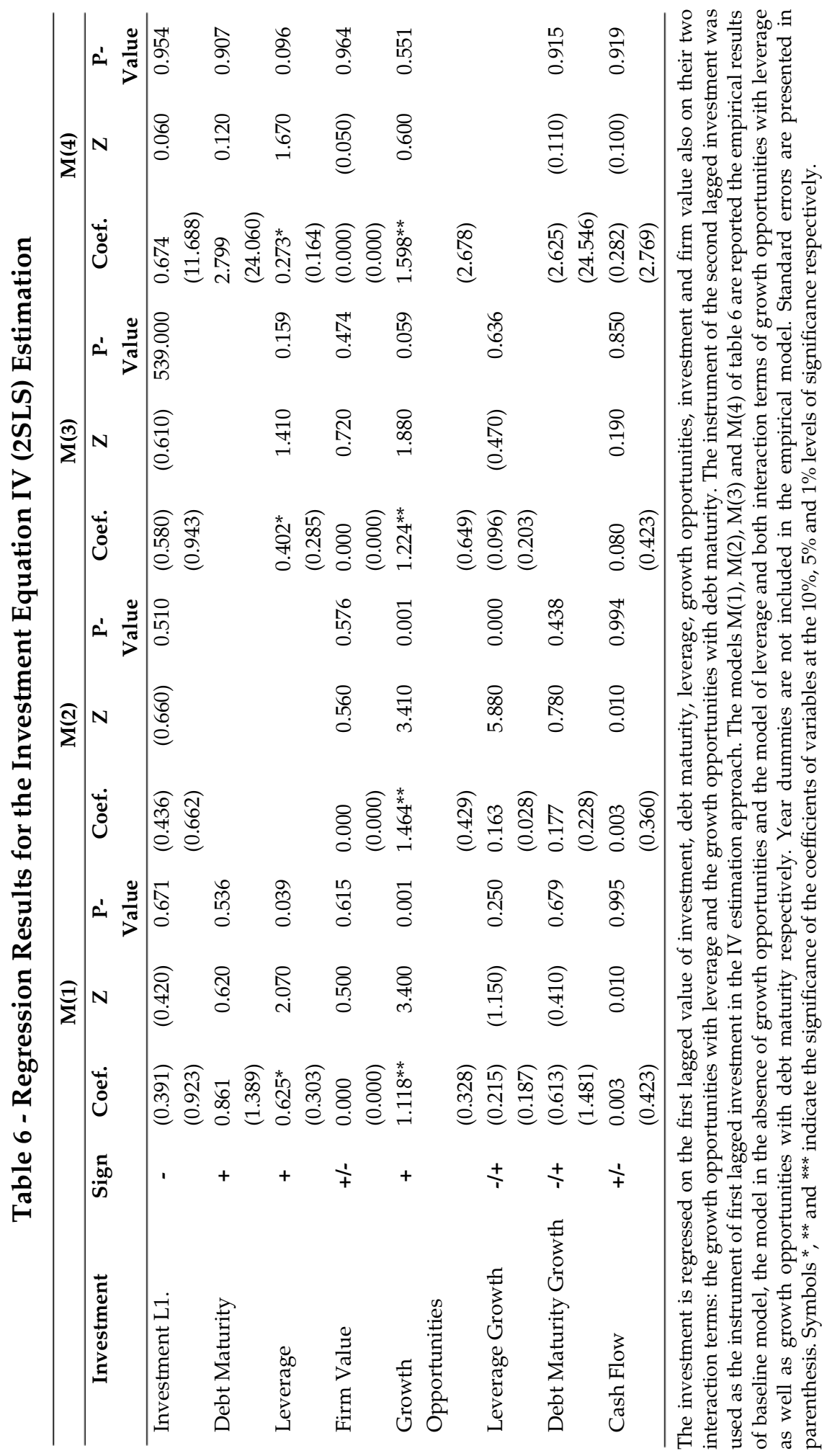




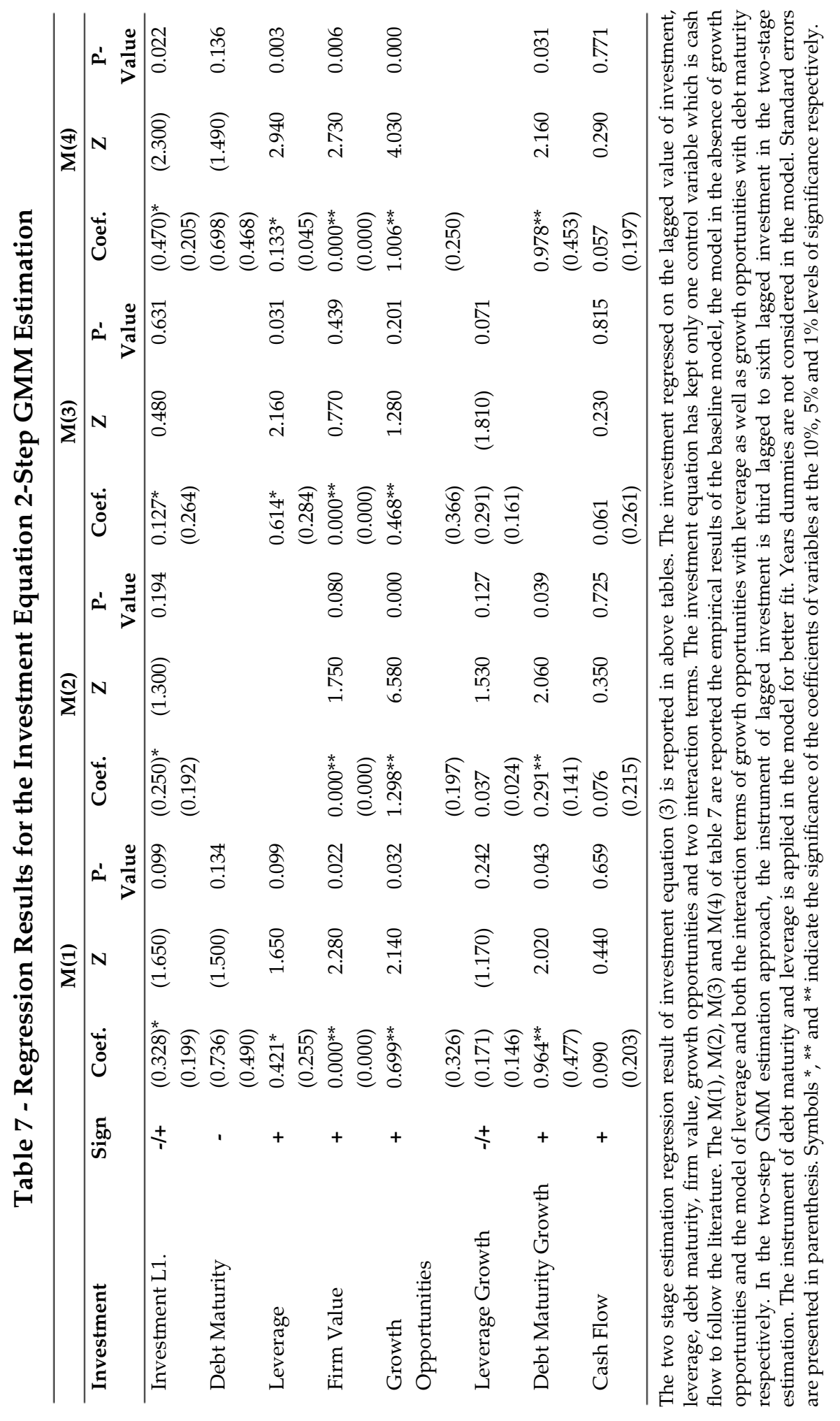


The investment equation regresses four times. The first regression is the baseline specification. Secondly, both the debt maturity and leverage are excluded from the model. In the third attempt, the model excludes the debt maturity and its interaction term growth opportunities from the original model. Finally, the interaction term of growth opportunities with leverage are absent from the baseline model. In all the eight models, the control variable cash flow does not reach significance with investment. Although it fails to reach significance, its positive direction is consistent with the literature (Aivazian, Ge, \& Qiu, 2005), and (Dang, 2011).

In the two-step GMM estimation approach, the instrument of lagged investment is third lagged to sixth lagged investment in the twostage estimation. The instrument of debt maturity and leverage is applied in the model for better fit. At a 10\% significance level, leverage has a significantly positive economic relationship with the investment in both baseline models. Leverage is also significant at 5\%,1\% in the third and fourth model of the two-step GMM estimator. These results are inconsistent with the (Aivazian, Ge, \& Qiu, 2005; Dang, 2011). Leverage and investment have negative relationships which support the underinvestment hypothesis. These results are reported from all eight models which are inconsistent with the results of (A Aivazian; Y Ge; J Qiu; 2005)The interaction term of growth opportunities and debt maturity is positively significant at the $5 \%$ significance level in all models of Table 7 . 


\subsection{Empirical Results of Firm Value Equation}

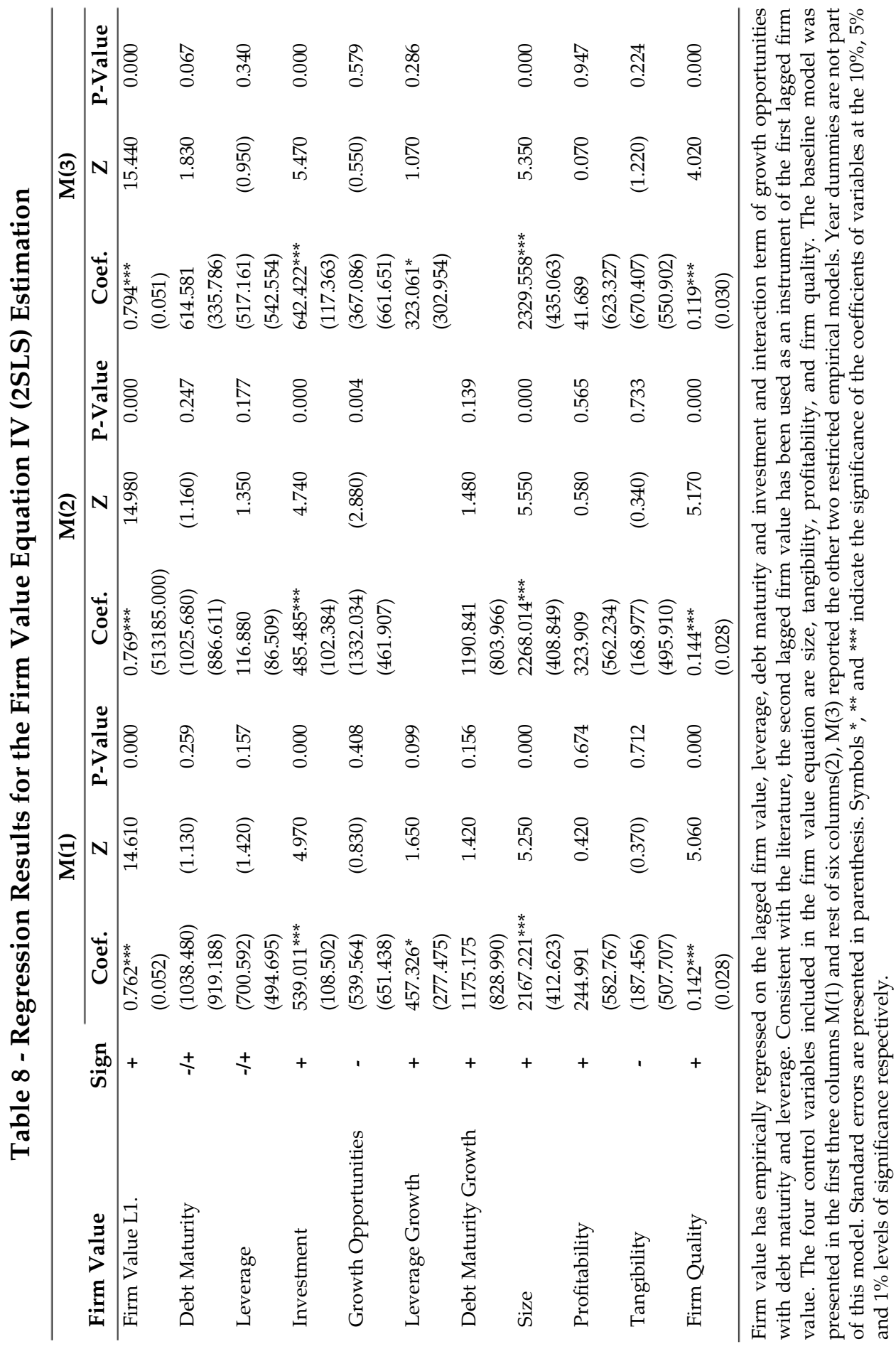




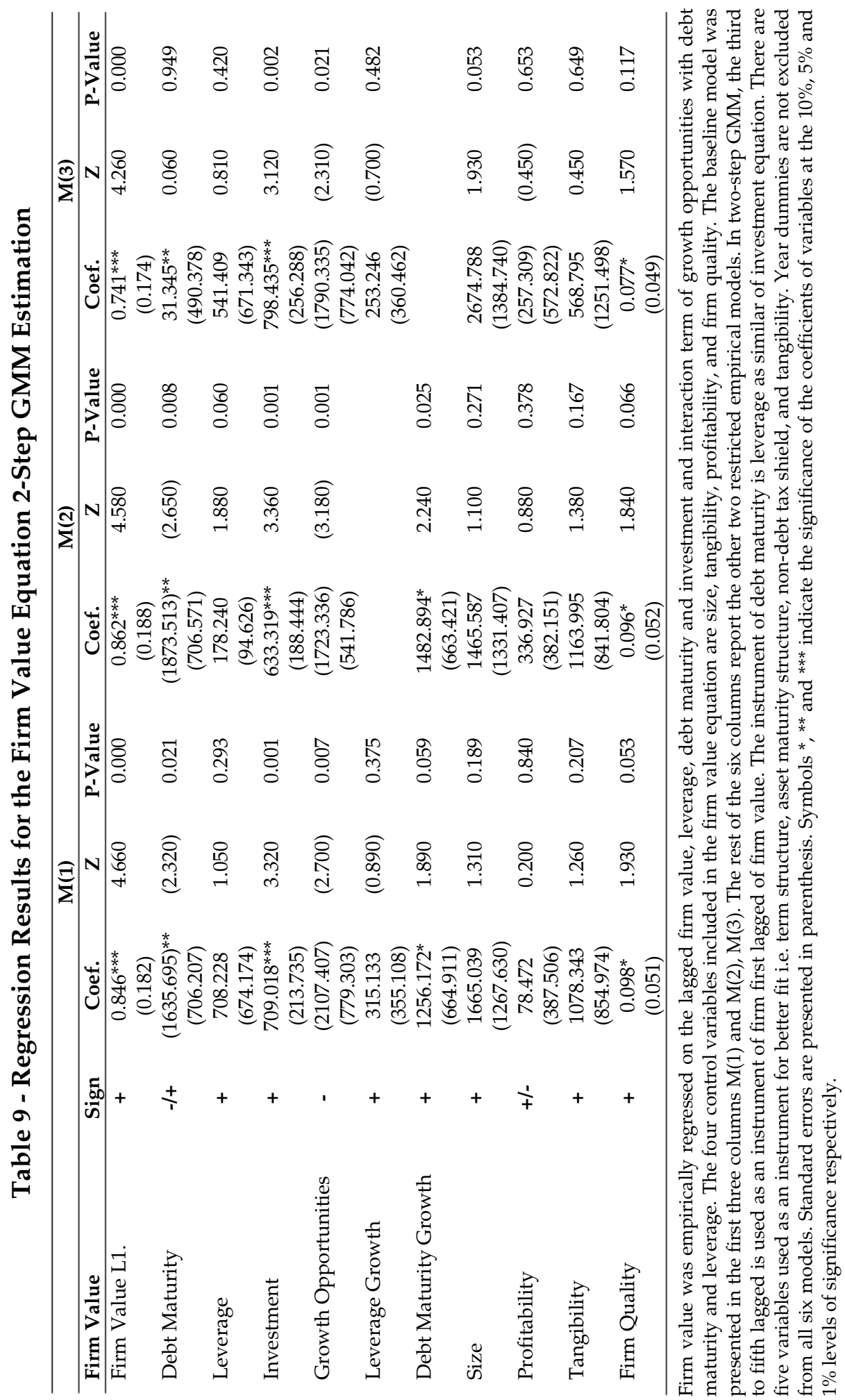


Lagged firm value is highly significant in all the six models at the $1 \%$ significance level. Based on the IV approach, firm size and firm quality are economically significant with the firm value. Firm quality is also significant at the $10 \%$ level in the results of the two-step GMM.

In the two-step GMM, first lagged of firm value is positively significant at the $1 \%$ level in all the models and debt maturity is negatively significant at the $5 \%$ level in model (1). This variable is significant and positive at the $1 \%$ level in model (2) and has no economic relationship in model (3) due to the potential attenuation effect. The previous literature suggests that debt maturity affects the firm value where managers have more information than the outside investors.

Leverage does not reach significance in any of the models except model (2) of the two-step GMM. The past iterature suggests that leverage has a positive relationship when the firm recognizes the potential investment opportunities or discourage the debt overhang. The relationship becomes negative when the firm does not accept the investment opportunities (Lang et al., 1996). Growth opportunities are negatively significant at the $1 \%$ level in all the (6) models.

\section{Final Conclusion and Discussion}

This paper investigated the growing trend of research on the interaction between firms' investment and financial decisions in the presence of the underinvestment problem. This research has addressed three main research questions. First, debt maturity and leverage are complements of each other, or not substitute to mitigate the underinvestment risk in the scenario of Pakistani firms. Second, it has examined the potential correlation among the firm's financing and investment decision. Thirdly, it examined how this interaction addresses the underinvestment and liquidity risk of non-financial Pakistani listed firms. Finally, the study investigated how growth firms mange the firm value using the mixed of debt maturity and leverage strategy.

This paper found that growth opportunities have a positive relationship with leverage. Firms in growth are more dependent on external funds, so we concluded that growth firms adopted the high leverage strategy which is consistent with the underinvestment hypothesis (Myers, 1977). The debt maturity and leverage have an economic significant relationship which supports these arguments. The debt maturity and leverage are complements and never substitute to 
control the underinvestment and liquidity risk. These results are consistent with the previous literature (Aivazian et al., 2005) and (Dang, 2011). Avoidance of <insert variable here $>$ was found by Pakistani firms that was not planned before the growth opportunities. This may be done to adopt the low leverage strategy ex ante to capture the growth opportunities ex post. This study also empirically investigated that the Pakistani firms do not use properly the structure of debt maturity to mitigate the potential risk. However the investment has a weak but significant relationship with the debt maturity. Further study should be conducted on the overinvestment problem, bondholder and underinvestment incentive, derivative and under/overinvestment problem, especially from the Pakistani perspective.

\section{Policy Recommendation}

Debt maturity and leverage are complements, not substitutes of each other in the design of the financial and investment policy. Both strategic variables played an important role to mitigate the underinvestment risk and liquidity risk. For high growth, firms must give more importance to the underinvestment risk, and for low growth, firms more focus on liquidity risk. Firms with high growth should rely more on low leverage strategy ex ante to anticipate the future growth opportunities ex post. This study found that leverage has a negative relationship with debt maturity which enhances the liquidity risk. Pakistani firms adopted the short-term debt to capture growth opportunities. Firms must use the debt maturity with respect to moderate the liquidity and underinvestment risk.

Furthermore, this study found that growth opportunities have a positively significant relationship with investment. Pakistani firms have not actively used the tool of debt maturity to mitigate the underinvestment or liquidity risk. Firms must adopt the low leverage strategy to anticipate the valuable growth opportunities. Debt maturity was found to have no economic significant relationship with investment with respect to non-financial, Pakistani sectors. Pakistani firms should actively consider the debt maturity structure to mitigate potential risk. It must also consider that these policy variables affect the firm value. Firms must set the capital structure and investment policy ex ante to capture the potential positive NPV projects which has the effect of avoiding the debt overhang and has a positive impact on firm value. 


\section{References}

Aivazian, V. A., Ge, Y., \& Qiu, J. (2005). The impact of leverage on firm investment: Canadian evidence. Journal of corporate finance, 11(1-2), 277-291.

Al Taleb, G., \& Al-Shubiri, F. N. (2011). Capital Structure Decisions And Debt Maturity Structure: An Empirical Evidence From Jordan. The Journal of Commerce, 3(4), 49.

Alcock, J., Finn, F., \& Tan, K. J. K. (2012). The determinants of debt maturity in Australian firms. Accounting E Finance, 52(2), 313-341.

Antoniou, A., Guney, Y., \& Paudyal, K. (2006). The determinants of debt maturity structure: evidence from France, Germany and the UK. European Financial Management, 12(2), 161-194.

Arslan, Ö. (2008). Ownership and control structure as determinants of corporate debt maturity: a panel study of an emerging market. Corporate Governance: an international review, 14(4), 312-324.

Barclay, M. J., \& Smith, C. W. (1995). The maturity structure of corporate debt. the Journal of Finance, 50(2), 609-631.

Becher, D. A., Mulherin, J. H., Walkling, R. A., Oberlechner, T., Osler, C., González, M., .. . Cici, G. (2012). Joseph PH Fan, Sheridan Titman, and Garry Twite.

Billett, M. T., KING, T. H. D., \& Mauer, D. C. (2007). Growth opportunities and the choice of leverage, debt maturity, and covenants. The Journal of Finance, 62(2), 697-730.

Bodie, Z., \& Taggart, R. A. (1978). Future investment opportunities and the value of the call provision on a bond. The Journal of Finance, 33(4), 1187-1200.

Brockman, P., Martin, X., \& Unlu, E. (2010). Executive compensation and the maturity structure of corporate debt. The Journal of Finance, 65(3), 1123-1161.

Conroy, R. (2009). Capital Structure and Firm Value. Darden Case No. UVA-F-0942. Available at https://ssrn.com/abstract=1417863 
Dang, V. A. (2011). Leverage, debt maturity and firm investment: An empirical analysis. Journal of business finance $\mathcal{E}$ accounting, 38(1-2), 225-258.

Easterwood, J. C., \& Kadapakkam, P.-R. (1994). Agency conflicts, issue costs, and debt maturity. Quarterly Journal of Business and Economics, 69-80.

Fama, E. F., \& French, K. R. (1998). Taxes, financing decisions, and firm value. The Journal of Finance, 53(3), 819-843.

Fernandez, V. (2011). The Driving Factors of Firm Investment: Latin American Evidence. Emerging Markets Finance and Trade, 47(5), 4-26.

Goyal, V. K., Lehn, K., \& Racic, S. (2002). Growth opportunities and corporate debt policy: the case of the US defense industry. Journal of financial Economics, 64(1), 35-59.

Haugen, R. A., \& Senbet, L. W. (1978). The insignificance of bankruptcy costs to the theory of optimal capital structure. The Journal of Finance, 33(2), 383-393.

Houston, J. F., \& Venkataraman, S. (1994). Optimal maturity structure with multiple debt claims. Journal of Financial and Quantitative Analysis, 29(02), 179-197.

Johnson, S. A. (2003). Debt maturity and the effects of growth opportunities and liquidity risk on leverage. Review of Financial Studies, 16(1), 209-236.

Korajczyk, R. A., \& Levy, A. (2003). Capital structure choice: macroeconomic conditions and financial constraints. Journal of financial economics, 68(1), 75-109.

Lang, L., Ofek, E., \& Stulz, R. (1996). Leverage, investment, and firm growth. Journal of financial economics, 40(1), 3-29.

Lewellen, W. G., \& Emery, D. R. (1986). Corporate debt management and the value of the firm: Cambridge Univ Press.

Lin, F.-L., \& Chang, T. (2011). Does debt affect firm value in Taiwan? A panel threshold regression analysis. Applied Economics, 43(1), 117-128. 
Majumdar, R. (2012). The Determinants of Indebtedness in Unlisted Manufacturing Firms in India: A Panel Data Analysis.

Masulis, R. W. (1983). The impact of capital structure change on firm value: Some estimates. The Journal of Finance, 38(1), 107-126.

Mauer, D. C., \& Triantis, A. J. (1994). Interactions of corporate financing and investment decisions: A dynamic framework. the Journal of Finance, 49(4), 1253-1277.

Modigliani, F., \& Miller, M. H. (1963). Corporate income taxes and the cost of capital: a correction. The American economic review, 53(3), 433-443.

Myers, S. C. (1977). Determinants of corporate borrowing. Journal of financial economics, 5(2), 147-175.

Ozkan, A. (2001). Determinants of capital structure and adjustment to long run target: evidence from UK company panel data. Journal of Business Finance \& Accounting, 28(1-2), 175-198.

Taleb, G. A., \& AL-Shubiri, F. N. Capital Structure Decisions and Debt Maturity Structure: An Empirical Evidence from Jordan. The Journal of Commerce, 3(4), 49-60

Ting, C. C. (2012). Market Value of the Firm, Market Value of Equity, Return Rate on Capital and the Optimal Capital Structure. International Journal of Financial Research, 3(4), p1.

Tsurutani, B. T., \& Smith, E. J. (1986). Strong hydromagnetic turbulence associated with comet Giacobini-Zinner. Geophysical research letters, 13(8), 259-262. 